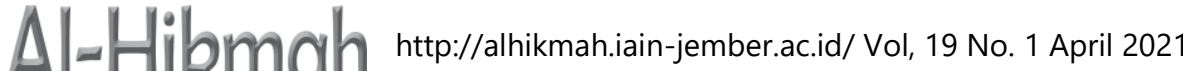 P-ISSN:1907-4328, E-ISSN : 2685-4376/P. 27-38
}

\section{Dakwah Transformatif Menciptakan Karakter Pemuda Islami (Studi Kasus Majelis Gaul Jember)}

\author{
Nur Kamilah \\ Universitas Islam Negeri Sunan Ampel Surabaya \\ nurkamilah@gmail.com
}

\begin{abstract}
There has been a spreading phenomenon in which many of today's youth societies tend to go wild and out of control. Most of such functions tend to be surrounded by individuals who indulge themselves in sinful acts instead of doing a self-discovery process to gain the God's blessings. Having seen many youths tend to enjoy doing forbidden acts and restrain-free activities, therefore Majlis Gaul community proposed a new way of da'wah. The community employs a subtle and a heart warming way of conveying da'wah. It is no longer conventional preaching which is in the form of oral da'wah, but they employ transformative da'wah method. This transformative da'wah is implemented in social change activities, by using da'wah as a religious material and positioning the dai (preacher) as the conveyer of religious messages to the community. The current study is a qualitative research with descriptive qualitative approach. In this study, the data are presented in descriptive texts. The results of this study are: 1) In shaping the Islamic character, Majlis Gaul community held a "Brother Camp" as well as some "Kajian Inspirasi". 2) Majlis Gaul invited Muslim youths to join activities such as sports (archery and horse riding). 3) The transformative da'wah done by Majlis Gaul was carried out by means of dialogue, exchanging thoughts and feelings. 4) The effort of Majlis gaul to do transformative da'wah is carried out by preaching through social media. This is because preaching through social media has become an increasingly globalized and entrenched phenomenon.
\end{abstract}

Keywords: Transformative Da'wah, Majlis Gaul, Islamic Youth Character.

\begin{abstract}
Abstrak
Melihat fenomena bahwa masih banyak pergaulan anak-anak muda di zaman sekarang. Semakin liar dan tak terkontrol. Lebih mengandalkan hawa nafsu dibanding mencari jati diri sebaik-baiknya guna mendapatkan rị̣ā ilāhī. Melihat pemuda-pemuda saat ini lebih suka hal yang bebas, dan senang-senang. Tidak suka ada tekanan apapun. Maka Komunitas Majelis Gaul dalam menyiarkan dakwah dengan lembut dan penuh kasih sayang. Bukan lagi dakwah konvensional yang berbentuk lisan. Yang disampaikan oleh dai-dai dalam berdakwah. Tetapi juga menggunakan metode dakwah transformatif. Yaitu dakwah Tetapi juga lebih pada kegiatan perubahan sosial, dengan menggunakan dakwah sebagai materi keagamaan dan memposisikan dai sebagai penyebar pesan keagamaan kepada masyarakat. Maka pada penelitian ini peneliti menggunakan metode pendekatan kualitatif dengan jenis
\end{abstract}


penelitian kualitatif deskriptif. Bahwa dalam penelitian kualitatif adalah penelitian dengan "prosedur penelitian yang menghasilkan data secara deskriptif. Hasil dari penelitian ini 1) Dalam membentuk karakter islami, komunitas majelis gaul pemuda Jember mengadakan Brother Camp juga kajian inspiratif. 2) Majelis Gaul mengajak pemuda-pemudi untuk mengisi dengan kegiatan yang bermanfaat seperti olahraga (memanah dan berkuda). 3) Dakwah transformatif yang dilakukan Majelis Gaul dilakukan dengan dialog, bertukar pikiran dan perasaan. 4) Upaya Majelis Gaul berdakwah Transformatif dilakukan dengan berdakwah melalui media sosial. Karena berdakwah dengan media sosial (medsos) telah menjadi fenomena yang semakin mengglobal dan mengakar.

Kata Kunci: Dakwah Transformatif, Majelis Gaul, Karakter Pemuda Islami.

\section{Pendahuluan}

Dalam melakukan perubahan sosial di zaman sekarang, yang mana perubahan yang mengarah pada hal yang lebih baik. Melihat fenomena bahwa masih banyak pergaulan anak-anak muda di zaman sekarang. Semakin liar dan tak terkontrol. Lebih mengandalkan hawa nafsu dibanding mencari jati diri sebaikbaiknya guna mendapatkan riḍ̄a ilāhī. Maka dakwah pada zaman ini lebih sulit untuk diwujudkan dalam kehidupan sehari-hari sesuai dengan tuntunan agama pada kehidupan yang riil dan lebih adil. Dan jika kita hanya menggunakan pendekatan dakwah yang biasa digunakan oleh dai-dai atau pendakwah seperti biasanya, dalam arti dakwah konvensional. Di depan anak-anak muda maka hal tersebut tidak akan berjalan signifikan. Melihat pemuda-pemuda saat ini lebih suka hal yang bebas, dan senang-senang. Tidak suka ada tekanan apapun oleh karena itu hal ini, atau keadaan ini sudah begitu kompleks. Dibutuhkan usaha lebih lagi demi mendapatkan kepercayaan pemuda-pemuda masa kini maka dibutuhkan dakwah yang berorientasi pada perubahan sosial, salah satunya dakwah transformatif apalagi di hadapan kalangan muda yang lebih kritis tentang segala hal. Perlu adanya strategi atau harapan baru dari wajah metode dakwah yang cocok untuk anak muda masa kini.

Ada juga yang berdakwah dengan pesan dakwah non-verbal, tidak dalam bentuk kata, ucapan, atau tulisan, tetapi dalam kebijakan manajemen. Dan Juga pendakwah yang memfokuskan dakwahnya untuk menyelamatkan iman generasi Muslim, sebagai contoh adanya kegiatan yang dilakukan oleh 35 pelajar Muslim Indonesia. Dan mereka dapat dikatakan sebagai remaja muslim. Dan dapat dikatakan sebagai perwakilan dari generasi muda yang peduli. Mereka tergabung dalam Keluarga Besar Britania Raya (KIBAR). Dan mereka menulis dua jilid buku tebal yang berjudul Paket Permainan Interaktif Pendidikan Akidah untuk Anak TK. Dan buku ini menjadi pegangan guru Islam yang mengajar keimanan untuk anak- 
anak diplomat, pelajar ataupun pekerja di Inggris. ${ }^{1}$ Menurut Geovanni, pemrakarsa penulisan, terbitnya buku tersebut dilatarbelakangi oleh kesulitan dalam pengajaran agama bagi anak-anak Muslim di Sheffield dan Inggris pada umumnya. Anak-anak dibiasakan untuk bersikap kritis termasuk dalam masalah agama, sehingga model pendidikan agama di Indonesia tidak bisa diterapkan sama sekali. Usaha KIBAR tersebut dapat dikatakan sebagai kegiatan dakwah dengan tulisan. Siapa pun bisa menjadi pendakwah dengan menulis pesan Islam di majalah, koran, atau internet.

Dan dalam penelitian ini peneliti lebih khusus menganalisis bagaimana metode dakwah transformatif. Dakwah non-verbal yang dapat diterapkan kepada generasi muda Kabupaten Jember. Dan dakwah tersebut sudah dilakukan oleh komunitas Majelis Gaul Jember kabupaten Jember. Pada Komunitas kajian pemuda millineal dengan berbagai kegiatan.

Dakwah semestinya dipahami sebagai suatu aktivitas yang melibatkan proses transformasi yang memang tidak terjadi begitu saja, tapi membutuhkan kesadaran dari masyarakat untuk merubah situasi dan kondisi mereka melalui pendidikan dan komunikasi yang berkelanjutan. Hal ini berarti sangat terkait dengan upaya rekayasa sosial. Sasaran utama dakwah adalah terciptanya suatu tatanan sosial yang di dalamnya hidup sekelompok manusia dengan penuh kedamaian, keadilan, keharmonisan di antara keragaman yang ada, yang mencerminkan sisi Islam sebagai rahmatan li al-'alamīn. ${ }^{2}$

Komunitas Majelis Gaul dalam menyiarkan dakwah dengan lembut dan penuh kasih sayang. Hal ini yang menjadi kunci sukses Majelis tersebut dapat mengumpulkan 2000 jamaah muda di Masjid Riad\}atul Mukhlisi>n di Grand launching nya pada tahun 2018. Hal ini sesuai dengan apa yang dilakukan Rasulullah $\square$. Salah satu faktor yang mendukung keberhasilan Nabi Muhammad dalam menyampaikan dakwah Islam kepada masyarakat adalah pribadi beliau yang lemah-lembut, santun dan menjauhi cara-cara kekerasan. Nabi Muhammad $\square$ hadir dalam panggung sejarah sosial yang penuh konflik dengan menampilkan pribadi yang lembut dan penuh belas-kasih bukan hanya kepada kawan tetapi juga kepada orang yang memusuhi beliau. Sikap yang akomodatif dan pantang kekerasan itu bahkan sudah terlihat sejak Muhammad belum diangkat menjadi Nabi oleh Allah 䦕. Dalam penelitian ini membahas bagaimana bentuk upaya dakwah transformatif yang sudah dilakukan oleh komunitas Majelis Gaul Kabupaten Jember pada pemuda millenial?

${ }^{1}$ Muhammad Qadaruddin Abdullah, Pengantar Ilmu Dakwah (CV. Penerbit Qiara Media, 2019), 3.

2 Ahmad Shofi Muhyiddin, "Dakwah Transformatif Kiai (Studi terhadap Gerakan Transformasi Sosial KH. Abdurrahman Wahid)," Jurnal Ilmu Dakwah 39, no. 1 (24 Oktober 2019): 2, https://doi.org/10.21580/jid.v39.1.3934. 


\section{Metode Penelitian}

Metode yang digunakan yaitu pendekatan kualitatif dengan jenis penelitian kualitatif deskriptif. Bahwa dalam penelitian kualitatif adalah penelitian dengan "prosedur penelitian yang menghasilkan data secara deskriptif yang mana data didapatkan adalah data yang berupa kata-kata tertulis atau lisan dari orang-orang dan prilaku yang dapat diamati”. Sedangkan dalam teknik pengumpulan data dalam penelitian ini peneliti menggunakan teknik pengumpulan data secara wawancara, observasi, dan dokumentasi.

Adapun yang menjadi narasumber dalam wawancara yaitu ustadz pendiri komunitas, para pemuda yang berada dalam komunitas. Peneliti melakukan observasi dan dokumentasi selama kegiatan komunitas berlangsung. Dalam penelitian ini teknik analisis data yang digunakan pada penelitian ini dengan menggunakan analisis diskriptif kualitatif. Dalam menganalisis data hasil penelitian, peneliti menggunakan Metode meliputi pengumpulan data (data collection), kondensasi data (data condensation), penyajian data (data display), dan penarikan kesimpulan (conclusion). Sedangkan untuk mendapatkan keabsahan data, peneliti menggunakan beberapa teknik yaitu perpanjangan keikutsertaan, atau observasi partisipan dan juga tringulasi. ${ }^{3}$

\section{Definisi Istilah}

1. Dakwah Transformatif

Dakwah transformatif yaitu salah satu model dakwah yang tidak mengandalkan sosialisasi dakwah menggunakan metode dakwah verbal (konvensional) saja. Tetapi juga lebih pada kegiatan perubahan sosial, dengan menggunakan dakwah sebagai materi keagamaan dan memposisikan dai sebagai penyebar pesan keagamaan kepada masyarakat. Dengan cara menginternalisasikan semua pesan dari materi tersebut langsung ke dalam kehidupan riil dan adanya pendampingan secara langsung.

Dakwah transformatif, menurut Ahidul Asror adalah gerakan dakwah yang dilakukan oleh Nabi Muhammad saw dengan tujuan untuk menata masyarakat agar lebih baik. dakwah transformatif lebih kepada dakwah yang mengacu kepada: (1) upaya memecahkan masalah yang berkembang secara konkrit dalam wilayah kehidupan sosial, (2) upaya menciptakan sistem hidup yang penuh moral dan kemanusiaan (full of morality and humanity System) (3) upaya mengaktualisasikan nilai-nilai Islam dalam segala aspek kehidupan perorangan (fardiyyah), keluarga (usrah), kelompok (țā'ifah), masyarakat (mujtama') dan negara (daulah), dan (4) upaya mewujudkan Islam sebagai tatanan masyarakat secara menyeluruh ( $k \bar{a} f f a h)$ dalam seluruh aspek kehidupan: ideologi, politik, social, budaya, ekonomi, dan

\footnotetext{
${ }^{3}$ Tarjo, Metode Penelitian Sistem 3x Baca (Deepublish, 2019), 29.
} 
pendidikan. ${ }^{4}$

\section{Dakwah}

Pemaparan definisi dakwah yang demikian banyak tersebut dimaksudkan untuk membandingkan, memetakan, dan menelusuri perkembangan definisi dakwah. Umumnya para ahli membuat definisi dakwah berangkat dari pengertian dakwah menurut bahasa. Kata-kata seruan, anjuran, ajakan, dan panggilan selalu ada dalam definisi dakwah. Ini menunjukkan bahwa dakwah bersifat persuasif, bukan represif. Mereka setuju dengan dakwah informatif, bukan manipulatif. Bukanlah termasuk dakwah, jika ada tindakan yang memaksa orang lain untuk memilih antara hidup sebagai Muslim ataukah mati terbunuh. Tidaklah disebut dakwah, bila ajakan kepada Islam dilakukan dengan memutarbalikkan pesan islam untuk kepentingan duniawi seseorang atau kelompok.

\section{Karakter}

Doni Koesoema A. Mengatakan bahwa definisi karakter adalah salah satu unsur dari psikososial yang dikaitkan dengan pendidikan dan sosial lingkungan. Karakter dapat dikatakan sebagai sudut pandang atau behavior yang menekankan unsur kepribadian yang dimiliki individu sejak lahir.

Karakter dianggap sama dengan kepribadian. Definisi dari kepribadian adalah ciri atau karakteristik dapat dikatakan juga sebagai sifat khas dari diri seseorang yang bersumber dari lingkungan.

Menurut Wynne karakter dapat dikatakan sebagai "to mark" atau (menandai) dan lebih pada bagaimana memfokuskan dan mengaplikasikan nilai kebaikan dalam bentuk tindakan dan perilaku sehari-hari. Oleh sebab itu, seseorang dapat dikatakan sebagai orang yang berkarakter baik. Apa bila seseorang yang mengaplikasikan nilai kebaikan dalam bentuk perbuatan, tindakan atau tingkah laku seperti sikap yang baik, perbuatan yang dapat dipertanggung jawabkan, saling menghormati dan jujur. Sedangkan seseorang orang yang berkarakter jelek. Adalah seseorang yang mengaplikasikan nilai keburukan atau kejelekan dalam bentuk perbuatan, tindakan atau tingkah laku. Maka dapat disimpulkan istilah karakter erat kaitannya dengan personality (kepribadian) seseorang.

Karakter yang baik berkaitan dengan melakukan yang baik (acting the good), mencintai yang baik (loving the good), mengetahui yang baik (knowing the good). ${ }^{5}$

4. Pemuda Millineal

William Strauss dan Neil dalam mencetuskan sejarah milenial pertama kali.

${ }^{4}$ Ahidul Asror, "Dakwah Transformatif Lembaga Pesantren Dalam Menghadapi Tantangan Kontemporer," Jurnal Dakwah 15, no. 2 (19 Desember 2014): 298, https://doi.org/ 10.14421/jd.2014.15204.

5 Ajat Sudrajat, "Mengapa Pendidikan Karakter?," Jurnal Pendidikan Karakter 1, no. 1 (4 Oktober 2011): 54, https://doi.org/10.21831/jpk.v1i1.1316. 
Dalam bukunya yang berjudul Millennials Rising: The Next Great Generation (2000). Yang mana Istilah ini diciptakan pada tahun 1987, ketika anak-anak yang lahir pada tahun 1982 masuk pra-sekolah.

Saat itu ditahun 2000 media mulai menyebut sebagai kelompok yang terhubung ke millennium baru di saat para remaja duduk dibangku SMA. Selain pendapat tersebut, pendapat lain oleh Elwood Carlson dalam bukunya yang berjudul The Lucky Few: Between the Greatest Generation and the Baby Boom (2008), menyebutkan bahwa generasi milenial adalah mereka yang lahir dalam rentang tahun 1983 sampai dengan 2001.

Sedangkan Hasanuddin Ali dan Lilik Purwandi dalam bukunya Millennial Nusantara menyebutkan bahwa Generasi milenial adalah mereka yang lahir antara tahun 1981 sampai dengan tahun 2000.

Manheim mendefinisikan generasi adalah suatu konstruksi sosial yang di dalamnya terdapat sekelompok orang yang memiliki kesamaan umur dan pengalaman dan memiliki historis kehidupan yang sama atau setara.

Dalam penelitian menurut Kupperschmidt generasi millenial adalah sekelompok individu yang mengidentifikasi kelompoknya berdasarkan kesamaan tahun kelahiran, umur, lokasi, dan kejadian-kejadian dalam kehidupan kelompok individu tersebut yang memiliki pengaruh signifikan dalam fase pertumbuhan mereka. ${ }^{6}$

5. Islami

Islami Secara terminologis, adalah agama wahyu yang mempunyai makna tauhid atau ke-Esaan Tuhan. Agama yang diturunkan oleh Allah 比 kepada Nabi Muhammad sebagai Rasulullah atau utusan Allah sebagai agama yang lengkap dan penutup. Hal ini berlaku bagi semua manusia di manapun, dan kapan pun, dengan ajaran tentang kehidupan manusia.

Menyampaikan wahyu kepada seluruh manusia tentang keyakinan dan ketentuan dalam menjalani kehidupan dan hubungan dengan Allah sesama manusia, dan alam lainnya. Bersumber dari Al-Qur'an yang bertujuan untuk memperoleh keridloan Allah, rahmat, kebahagiaan dunia dan akhirat, dengan menerangkan akidah, syariat, dan akhlak.

\section{Hasil Dan Pembahasan}

Berdasarkan hasil wawancara dan observasi yang dilakukan pada penelitian ini, beberapa hal yang membuat peneliti ingin menganalisis secara langsung. Apa penyebab dari kemerosotanya akhlak anak muda di kabupaten Jember pada

6 Suci Wahyu Fajriani, "Hijrah Islami Milenial Berdasarkan Paradigma Berorientasi Identitas," Sosioglobal: Jurnal Pemikiran dan Penelitian Sosiologi 3, no. 2 (13 Juli 2019): 83, https://doi.org/10.24198/jsg.v3i2.21643. 
khsusunya. Salah satunya adanya waktu yang dipakai dia-sia oleh anak muda. Lebih mengikuti hawa nafsu. Sesuai data yang diterima mereka berpendapat bahwa Menurut informan, pemuda di Jember itu macam-macam. Tapi lebih dominan yang kurang mengalokasikan waktunya untuk hal-hal yang kurang bermanfaat. Yang saya lihat, masih langka anak muda yang ikut majelis atau kajian-kajian di hari libur kuliah. Lebih banyak yang sibuk jalan-jalanlah dan sibuk sama pacar. Sedangkan berpacaran adalah salah satu pintu terbukanya keburukan lainnya seperti zina dan membuang-buang waktu. Dan hal ini sudah dilarang oleh Allah mendekati zina dalam al-qur'an surat al isra ayat 23 berbunyi:

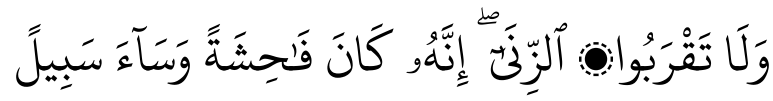

Dan janganlah kamu mendekati zina, sesungguhnya zina adalah suatu perbuatan yang keji. Dan suatu jalan yang buruk." (QS. Al-Isra: 32).

Maka adanya komunitas Majelis Gaul adalah salah satu solusi bagi anak muda Jember. Lebih produktif dalam kegiatan bukan hanya kegiatan yang manfaatnya didapatkan di dunia tapi juga sebagai ladang dakwah agar anak-anak muda mendapatkan ilmu akhirat dan tidak terjerumus dalam hawa nafsu belaka. Komunitas Majelis Gaul Yang didirikan oleh Ustadz Hutri pada tanggal 17 Agustus 2017. Awal terbentuk Majelis Gaul adalah dimulai dari kepedulian Ustadz Hutri terhadap generasi muda dan juga dan bagaimana beliau dapat berkontribusi untuk umat, agama, bangsa dan negara.

Sedangkan untuk visi dan misi Majelis Gaul tersebut adalah "uduwannas 'ala qodri ukulihim" berdakwaklah kepada manusia sesuai dengan kadar akalnya. Hal tersebut yang menarik perhatian pemuda millenial yang mau mengikuti komunitas ini. Karena segmen pada setiap kajian dicocokan dengan usia pemuda. Dengan tema-tema kajian atau pembahasan kajian yang sesuai dengan kadar akal jama'ah kalangan muda, maka tema-tema Majelis Gaul sekitar baper, jomblo dan wirausaha.

Kemudian Berikut upaya-upaya dakwah transformatif yang dilakukan oleh komunitas Majelis Gaul Jember.

\section{Upaya komunitas majelis gaul membentuk karakter islami pemuda Jember dengan mengadakan Brother Camp juga kajian inspiratif.}

Berdasarkan data dari peserta majelis gaul Jember. Yang juga adalah salah salah satu mahasiswi di salah satu kampus negeri mengatakan bahwa dalam kajian yang ada di majelis bau lebih pada pengajian tentang mengingat mati. Kajiannya juga kebanyakan seputar bagaimana menginspirasi anak muda tentang cara menghabiskan waktu dengan benar dan mengalokasikan tenaganya sehingga bermanfaat untuk umat atau masyarakat.

Dapat dikatakan bahwa Majelis gaul Jember menerapkan langsung menerapkan beragam upaya dalam rangka menumbuhkan karakter Islami 
tersebut. Tanpa harus menyelaraskan terlebih dahulu perbedaan-perbedaan yang beragam dari sekian banyak anggotanya. Disadari atau tidak, Komunitas ini secara perlahan mampu untuk merubah karakter seseorang dari yang awalnya kurang baik dibentuk menjadi pribadi yang memiliki karakter yang baik. Hal tersebut dikarenakan Komunitas yang semacam ini termasuk contoh contoh dalam menumbuhkan karakter bagi seseorang dari segi lingkungan yang baik dan benar.

Upaya dari komunitas Majelis Gaul menumbuhkan karakter Islami generasi Millineal di Jember Di antaranya kajian Islami inspiratif ini Menurut informan di lapangan juga mengatakan bahwa dampak dari mengikuti kajian tersebut sangat positif dan banyak manfaatnya, seperti dorongan kepada anak muda yang harus menjaga pergaulan. Di lingkungan orang-orang dengan pergaulan yang positif. Mengajak pada pergaulan yang islami dan menghindari hal-hal yang haram. Dalam Majelis Gaul informan mengatakan bahwa mengenal banyak orang. Dan mereka mendapatkan teman sholeh. Yang saling mengingatkan jika berbuat salah. Dan dengan sering mengikuti kajian, dapat men-charge iman. Yang diibaratkan keimanan seperti baterai bisa drop maka kalau manusia imannya naik turun. Dengan sering mengikuti kajian mereka menjadi lebih suka beribadah. Dan mereka berkeyakinan bahwa salah satu yang dilindungi di akhirat nanti yaitu pemuda yang tumbuh dalam beribadah.

\section{Upaya Majelis Gaul dengan kegiatan yang bermanfaat untuk pemuda seperti mengajarkan olahraga. Dan perlombaan olahraga.}

Seperti yang disampaikan oleh informan dalam penelitian ini bahwa di dalam Majelis Gaul pemuda Kabupaten Jember juga mengikuti olahraga Sunnah bersamasama dengan para peserta komunitas. Seperti memanah dan berkuda.

Apa yang dilakukan komunitas di Majelis Gaul sesuai dengan sunnah Rasulullah dalam hadis dikatakan.

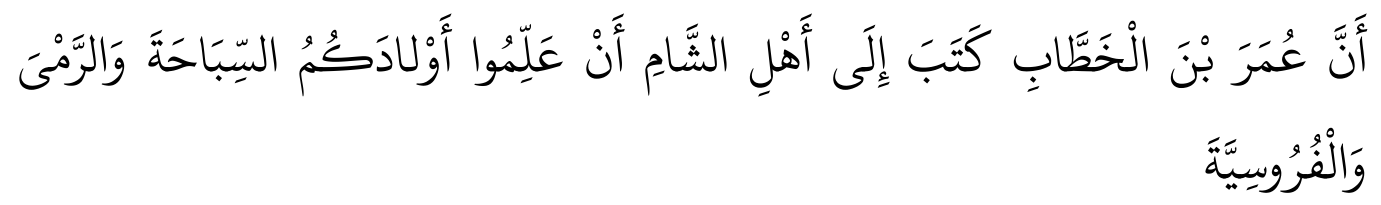

Umar bin Khattab telah mewajibkan penduduk Syam supaya mengajar anak-anak kamu berenang, dan memanah, dan menunggang kuda.

Berenang memiliki karakter 'gerak', di mana saat berenang kita harus terus menerus bergerak, karena jika diam, maka akan membayakan diri kita. Jika diterapkan dalam keseharian, filosofi berenang ini dimaksudkan agar kita harus selalu bekerja keras, tidak boleh bersantai-santai dalam hidup, dan selalu percaya diri.

Berkuda memiliki karakter mengendalikan dalam gerakan cepat. Seorang 34 | Nur Kamilah 
yang menunggang kuda harus berani dan mampu mengendalikan dirinya dan tunggangannya yang berlari sangat cepat. Pada kehidupan sehari-hari, filosofi berkuda ini dimaksudkan agar kita mampu jadi pemimpin yang berani, yang mampu mengendalikan dirinya dan usahanya dalam keadaan apapun, termasuk bila usaha kita harus bergerak cepat. ${ }^{7}$

\section{Upaya Majelis Gaul sebagai dakwah transformatif kepada pemuda Kabupaten Jember dengan dialog, bertukar pikiran dan perasaan.}

Seperti apa yang peneliti temukan bahwa di dalam Majelis Gaul para pemuda yang mengikuti setiap kegiatan di sana diajak berdiskusi dan berdialog. Menerima semua masukan dan juga tempat mencurahkan perasaan pemuda. Agar dakwah dan ajaran Islam sesuai dengan umur pemuda saat itu. Tidak monoton dan lebih pada memberi pandangan seluas-luasnya tentang budaya dan syariat yang ada dalam ajaran Islam. Salah satu contoh informan yang mengatakan pandangannya melihat jenggot, sorban dan cadar. Mereka mengatakan harus open minded atau berpikiran terbuka, berwawasan luas, dan selalu mengutamakan khusnudzon atau positif. "Misal loh mas itu kok berjenggot, ya berarti kita berpikir mungkin mas itu mengamalkan sunnah. Kan ada itu hadisnya. Barangsiapa yang menumbuhkan jenggot, maka setiap helainya berupa pahala. Terus misal melihat mbak-mbak bercadar, ya kita berpikir bahwa mbak itu menerapkan Islam yang lebih baik. Karena mungkin menutup dan menjaga auratnya. Jangan memvonis yang berjenggot atau bercadar teroris atau radikal atau dikira ikut aliran apalah. Karena setelah mengikuti berbagai kajian ormas ya kita itu harus mengutamakan berpikir positif. Karena antara muslim satu dengan muslim lainnya adalah saudara."

Metode dakwah pada komunitas Majelis Gaul untuk pemuda yaitu "mujadalah bi-lati hiya ahsan" yaitu dengan berdialog, bertukar pikiran dan perasaan untuk mendorong mereka agar menggunakan akal dan hatinya secara sehat, bisa juga. Dengan menyatukan 3 metode yaitu di awal berceramah lalu selanjutnya tanya jawab dan juga harus dilengkapi dengan uswah, yaitu melakukan apa yang diucapkan kepada orang lain agar para pemuda bersemangat dan tertarik dalam menyimak kajian, namun metode ceramah tidak terlalu lama dan diselingi dengan hal yang lucu. Karena menyesuaikan dengan kadar akal pemuda millenial. Metode dengan membawakan tema-tema yang relevan dengan kehidupan anak muda. Seperti menikah, jomblo dan lain sebagainya Majelis Gaul juga biasa mengadakan kajian di cafe yang memang banyak perkumpulan anak muda.

Dakwah dengan membuka wawasan. Berdialog dan mengutarakan pendapat dan mencurahkan perasaan adalah jalan dakwah transformatif. Seperti apa yang disampaikan oleh Isa Saleh dkk. yang mana sejak awal Islam hadir di muka bumi ini memiliki visi transformatif. Dengan kata lain, bukan sekedar perubahan akidah

\footnotetext{
${ }^{7}$ Yuli Farida, Ajari Anakmu Berenang, Berkuda, dan Memanah (MediaPressindo, 2013), 14.
} 
dari jāhiliyyah ke Islam, tetapi juga melakukan perubahan sosial dari masyarakat yang tidak adil, zalim, dan sewenang-wenang berubah menjadi masyarakat yang adil, damai, dan menghargai perbedaan kelas sosial. Karena itulah dakwah Islam yang dilakukan pertama kali memiliki visi yang jelas tentang landasan transformatif. Yakni, sikap teologis yang mengharuskan setiap kaum beragama untuk membawa dan membumikan ide-ide agama dalam pergulatan hidup secara kolektif untuk menegakkan tatanan sosial yang adil. Ini artinya Islam transformatif menyangkut upaya penafsiran terhadap wahyu yang memihak orang-orang tersingkir, tertindas dari mobilitas sosial, atau bahkan tar-subordinasi akibat developmentalisme, kapitalisme, serta pasar bebas yang lain menggurita. ${ }^{8}$

\section{Upaya Majelis Gaul berdakwah Transformatif. Dengan berdakwah melalui media sosial.}

Berdakwah dengan media sosial (medsos) telah menjadi fenomena yang semakin mengglobal dan mengakar. Dengan adanya media sosial para penyebar Syariah dan dai-dai yang menyebarkan dakwahnya semakin mudah. Sebagai bentuk aplikasi dalam komunikasi secara virtual, para pendakwah menggunakan media sosial yang merupakan hasil dari kemajuan Teknologi Informasi dan Komunikasi semakin mudah inovatif dan mudah. Apalagi zaman sekarang para pemuda adalah pengguna media sosial terbanyak. Berdakwah dengan media sosial merupakan dakwah transformatif dengan menyiarkan dakwahnya melalui media online, di mana para penggunanya melalui aplikasi berbasis internet dapat berbagi, berpatisipasi, dan menciptakan konten berupa blog, wiki, forum, jejaring sosial, dan ruang dunia virtual yang disokong oleh teknologi multimedia yang kian canggih. Pada saat ini situs-situs kajian islami dan berbagai ilmu, sudah ada di jejaring sosial, blog, dan wiki yang merupakan media sosial yang paling banyak digunakan dan tumbuh pesat di antara yang lainnya. ${ }^{9}$

Hal ini sama seperti apa yang dilakukan oleh Ustadz Hutri dalam Majelis Gaul beliau mengoptimalkan whatsApp, share di grup-grup tentang kegiatan dan bahan kajian, dengan memberikan chat pada masing-masing personil komunitas, selain di WhatsApp Majelis Gaul juga menggunakan aplikasi instagram. Dan instagram itu paling ampuh nomor 2 setelah whatsApp seru pendiri Komunitas Majelis Gaul ini. Setelah dua media sosial di optimalkan Majelis Gaul juga aktif di laman YouTube. Dan tiga mediasosial ini adalah 3 media sosial yang sering di kunjungi oleh para millenial. Maka strategi mengoptimalan media sosial sebagai bentuk dakwah transformatif adalah usaha pendekatan yang dilakukan oleh pengurus komunitas Majelis Gaul.

\section{Kesimpulan}

${ }^{8}$ Isa Saleh dan Adityo Nugroho, "Pentingnya Dakwah Transformatif Dalam Kehidupan Masyarakat," Masjiduna : Junal Ilmiah Stidki Ar-Rahmah 1, no. 1 (6 Juni 2018): 22.

${ }^{9}$ Eko Sumadi, "DAKWAH DAN MEDIA SOSIAL: Menebar Kebaikan Tanpa Diskrimasi," 148, diakses 26 April 2021, https://doi.org/10.21043/at-tabsyir.v1i2.2912. 
Dari hasil penelitian dan pembahasan di atas, penulis menarik kesimpulan sebagai berikut:

1. Membentuk karakter islami komunitas majelis gaul pemuda Jember mengadakan Brother Camp juga kajian inspiratif. dalam kajian yang ada di majelis lebih pada pengajian tentang mengingat mati. Juga seputar kajian yang menginspirasi anak muda tentang cara menghabiskan waktu dengan benar dan mengalokasikan tenaganya sehingga bermanfaat untuk umat atau masyarakat.

2. Majelis Gaul mengajak pemuda-pemudi untuk mengisi dengan kegiatan yang bermanfaat seperti olahraga dan perlombaan olahraga. Dalam Majelis Gaul pemuda Kabupaten Jember juga mengikuti olahraga Sunnah bersama-sama dengan para peserta komunitas, seperti memanah dan berkuda.

3. Dakwah transformatif yang dilakukan Majelis Gaul dilakukan dengan dialog, bertukar pikiran dan perasaan. Dakwah dan ajaran Islam sesuai dengan umur pemuda. Tidak monoton dan lebih pada memberi pandangan seluas-luasnya tentang budaya dan syariat yang ada dalam ajaran Islam. Salah satu contoh informan yang mengatakan pandangannya melihat jenggot, sorban dan cadar. Agar lebih open minded atau berpikiran terbuka, berwawasan luas, dan selalu mengutamakan khusnudzon atau positif.

4. Upaya Majelis Gaul berdakwah Transformatif dilakukan dengan berdakwah melalui media sosial. Berdakwah dengan media sosial (medsos) telah menjadi fenomena yang semakin mengglobal dan mengakar. Dengan adanya media sosial para penyebar Syariah dan dai-dai yang menyebarkan dakwahnya semakin mudah. Sebagai bentuk aplikasi dalam komunikasi secara virtual, para pendakwah menggunakan media sosial yang merupakan hasil dari kemajuan Teknologi Informasi dan Komunikasi semakin mudah inovatif dan mudah.

\section{Daftar Pustaka}

Abdullah, Muhammad Qadaruddin. Pengantar Ilmu Dakwah. CV. Penerbit Qiara Media, 2019.

Ahadiyanto, Nuzul. Hubungan Dimensi KepribadianThe Big Five Personality Dengan Tingkat Kesejahteraan Psikologis Narapidana. Jurnal AlHikmah, 2020, 18.1: 117-130.

Alwi, Muhammad Muhib. Pemberdayaan Ekonomi Masyarakat Berbasis Masjid di Tengah Pandemi Covid-19. Jurnal Al-Hikmah, 2020, 18.1: 99-116.

Al Ahsani, Nasirudin. "Kepemimpinan Perempuan Pada Masyarakat dalam Perspektif Sa īd Ramaḍān Al-Būțī (Telaah Hadis Misoginis)." Jurnal AlHikmah 18.1 (2020): 57-74. https://doi.org/10.35719/alhikmah.v18i1.23. . "Moderasi Beragama: Meninjau Hadis-Hadis Hukuman Mati Bagi Orang Murtad." Jurnal Al-Hikmah 18.2 (2020): 61-82. https://doi.org/10.35719/ alhikmah.v18i2.33.

Andriani, Nita. Strategi Komunikasi Bisnis Mini Market Islam Sebagai Pendidikan Kemandirian Santri. Jurnal Al-Hikmah, 2020, 18.2: 47-60.

Asror, Ahidul. "Dakwah Transformatif Lembaga Pesantren Dalam Menghadapi Tantangan Kontemporer." Jurnal Dakwah 15, no. 2 (19 Desember 2014): 
289-312. https://doi.org/10. 14421/jd.2014.15204.

Dawud, Mochammad. Menerapkan Manajemen Strategi Penyiaran untuk Penyiaran Dakwah. Jurnal Al-Hikmah, 2019, 17.1: 109-140.

Dawud, Mochammad; Choliq, Abdul. Manajemen Strategi Ala NU Tv 9 Menghadapi Televisi Swasta Lokal di Surabaya. Jurnal Al-Hikmah, 2020, 18.1: 75-98.

Elanda, Yelly. Komodifikasi Agama pada Perumahan Syariah di Surabaya. Jurnal Al-Hikmah, 2019, 17.1: 41-62.

Fauzi, Ahmad. Problematika Dakwah di Tengah Pandemi Covid 19 Mewabah. Jurnal Al-Hikmah, 2020, 18.1: 27-36.

Fitriani, Aprilya; SAVIRA, Amelia. Strategi Pengembangan Potensi Wisata Desa Bone-Bone Kabupaten Enrekang Provinsi Sulawesi Selatan. Jurnal Al-Hikmah, 2020, 18.2: 21-38.

Fajriani, Suci Wahyu. "Hijrah Islami Milenial Berdasarkan Paradigma Berorientasi Identitas." Sosioglobal : Jurnal Pemikiran dan Penelitian Sosiologi 3, no. 2 (13 Juli 2019): 76-88. https://doi.org/10.24198/jsg.v3i2. 21643.

Farida, Yuli. Ajari Anakmu Berenang, Berkuda, dan Memanah. MediaPressindo, 2013.

Hadi, H. Sofyan. Manajemen Strategi Dakwah di Era Kontemporer. Jurnal AlHikmah, 2019, 17.1: 79-90.

Isfironi, Mohammad. Kota Santri, Bumi Shalawat Nariyah dan BuleDhika. Jurnal Al-Hikmah, 2019, 17.1: 1-20.

Jannah, Hasanatul. Pondok Pesantren Sebagai Pusat Otoritas Ulama Madura. Jurnal Al-Hikmah, 2019, 17.1: 91-108.

Muhyiddin, Ahmad Shofi. "Dakwah Transformatif Kiai (Studi terhadap Gerakan Transformasi Sosial KH. Abdurrahman Wahid).” Jurnal Ilmu Dakwah 39, no. 1 (24 Oktober 2019): 1-14. https://doi.org/10.21580/jid.v39.1.3934.

Nafis, Abdul Wadud. Islam, Peradaban Masa Depan. Jurnal Al-Hikmah, 2020, 18.2: 1-20.

Putra, Ferdian Ardani; FAUZI, Ahmad. Komunikasi KPU Dalam Menekan Golput di Jember. Jurnal Al-Hikmah, 2020, 18.2: 95-108.

Rohmah, Mudrika; Musyarrofah, Anjumil; Sulistiyowati, Anugrah. Secure Attachment (Kelekatan Aman) Anak Usia Remaja Dengan Orang Tua Di Tengah Pandemi Covid-19. Jurnal Al-Hikmah, 2020, 18.2: 83-94.

Saleh, Isa, dan Adityo Nugroho. "Pentingnya Dakwah Transformatif Dalam Kehidupan Masyarakat.” Masjiduna : Junal Ilmiah Stidki Ar-Rahmah 1, no. 1 (6 Juni 2018): 17-28.

Sudrajat, Ajat. 'Mengapa Pendidikan Karakter?” Jurnal Pendidikan Karakter 1, no. 1 (4 Oktober 2011). https://doi.org/10.21831/jpk.v1i1. 1316.

Sumadi, Eko. "Dakwah Dan Media Sosial: Menebar Kebaikan Tanpa Diskrimasi." Diakses 26 April 2021. https://doi.org/10.21043/at-tabsyir. v1i2.2912.

Tarjo. Metode Penelitian Sistem 3x Baca. Deepublish, 2019. 